\title{
POLÍTICAS DO CORPO: ARTE E PSICANÁLISE DESPINDO AS IMAGENS
}

\author{
Policies of the Body: Art and Psychoanalysis Undressing the Images
}

Políticas del Cuerpo: Arte y Psicoanálisis Desnudando las Imágenes

\section{Politiques du Corps: De l'Art et de la Psychanalyse Déshabillent des Images}

DOI: $10.5020 / 23590777 . r s . v 18 i E s p .6148$

\begin{abstract}
Ana Lúcia Mandelli de Marsillac (Lattes)
Psicóloga, Psicanalista, Professora Adjunta C I do Departamento de psicologia da Universidade Federal de Santa Catarina. Professora do PPG em Psicologia UFSC .
\end{abstract}

Tomás da Cunha Tancredi (Lattes)
Estudante da graduação em Psicologia na UFSC.

João Gabriel Neves de Sousa (Lattes)

Psicólogo, formado pela Universidade Federal de Santa Catarina (UFSC).

\section{Resumo}

Este artigo é fruto do projeto de pesquisa: "Políticas do corpo: psicanálise e arte”. Debruça-se sobre as obras de dois artistas espanhóis, Ana Casas e Mira Bernabéu, que na virada do século XXI, colocam em questão o corpo em sua relação com o laço social. A leitura dessas obras é sustentada pela teoria psicanalítica, na perspectiva de Sigmund Freud e Jacques Lacan, através de uma estética negativa, debruçada sobre o estranho das imagens. Desse encontro entre arte e psicanálise, produz-se uma análise processual sobre o corpo na contemporaneidade, na qual se apresenta as obras, sublinhando suas singularidades e semelhanças temáticas. Aproxima esses saberes por suas políticas do corpo, em uma perspectiva crítica aos ideais dominantes de beleza, juventude, saúde perfeita e completude. Analisa que o encontro com o outro, com a cultura, com as imagens e a materialidade do corpo torna possível construir ideais singulares, auxiliando o sujeito a lidar com a incompletude inerente ao humano. O artigo é apresentado na seguinte estrutura: "Psicanálise e arte: políticas do corpo", em que se introduz o artigo e o encontro conceitual; "Obra e corpo", com os subitens: "Mira" e "Casas", apresentando as obras em questão; "O familiar e o estranho", com os subitens: "Despir o corpo" e "Desmembrar o corpo", que envolvem a articulação conceitual entre as obras e conceitos psicanalíticos e; por fim, à guisa de conclusão, apresenta-se: "Ideal do corpo", em que se busca articular os ideais de corpo na contemporaneidade, com as perspectivas críticas introduzidas pelas obras e pela psicanálise.

Palavras-chave: corpo; arte; psicanálise; imagem e contemporaneidade.

\section{Abstract}

This article is the result of the research project: "Policies of the body: psychoanalysis and art". It focuses on the works of two Spanish artists, Ana Casas and Mira Bernabéu, who at the turn of the 21st century, question the body in its relation to the social bond. The reading of these works is supported by psychoanalytic theory, in the perspective of Sigmund Freud and Jacques Lacan, through a negative aesthetic, leaning on the strange of the images. From this encounter between art and psychoanalysis, a procedural analysis is produced on the body in the contemporary world, in which the works are presented, emphasizing their singularities and thematic similarities. It approaches this knowledge by its policies of the body, in a critical perspective to the dominant ideals of beauty, youth, perfect health and completeness. It analyzes that the encounter with the other, with the culture, with the images and materiality of the body makes it possible to construct singular ideals, helping the subject to deal with the inherent incompleteness of the human. The article is presented in the 
following structure: "Psychoanalysis and art: politics of the body", in which the article and the conceptual encounter are introduced; "Work and body", with sub-items: "Mira" and "Houses", presenting the works in question; "The familiar and the strange", with the sub-items. "Undress the body" and "Dismember the body", which involve the conceptual articulation between psychoanalytic works and concepts and; finally, as a conclusion, we present: "Ideal of the body", in which one seeks to articulate the ideals of body in the contemporary world, with the critical perspectives introduced by works and by psychoanalysis.

Keywords: body; art; psychoanalysis; image and contemporaneity.

\section{Resumen}

Este artículo es fruto del proyecto de investigación: "Políticas del cuerpo: psicoanálisis y arte". Se hecha sobre las obras de dos artistas españoles, Ana Casas y Mira Bernabéu, que en la pasada del siglo XXI, pusieron en cuestión el cuerpo y su relación con el lazo social. La lectura de estas obras es sujetada por la teoría psicoanalítica, en la perspectiva de Sigmund Freud y Jacques Lacan, por medio de una estética negativa acostada sobre sobre el raro de las imágenes. De este encuentro entre arte y psicoanálisis, se produjo un análisis procesual sobre el cuerpo en la contemporaneidad, en la cual se presentan las obras, subrayando sus singularidades y semejanzas temáticas. Acerca estos saberes por sus políticas del cuerpo, en una perspectiva crítica a los ideales dominantes de belleza, juventud, salud perfecta y plenitud. Analiza que el encuentro con el otro, con la cultura, con las imágenes y la materialidad del cuerpo posibilita construir ideas singulares, auxiliando el sujeto a lidiar con la falta de plenitud inherente al ser humano. El artículo es presentado en la siguiente estructura: "Psicoanálisis y arte: políticas del cuerpo", en la que se introduce el artículo y el encuentro conceptual; "Obra y cuerpo", con los sub-puntos: "Mira" y "Casas", presentando las obras en cuestión; "El familiar y el raro", con los sub-puntos: "Desnudar el cuerpo" y "Desarticular el cuerpo", que envuelven la articulación conceptual entre las obras y conceptos psicoanalíticos y, por fin, a la conclusión están: "Ideal del cuerpo”, en la que se busca articular los ideales del cuerpo en la contemporaneidad, con las perspectivas críticas introducidas por las obras y por el psicoanálisis.

Palabras clave: cuerpo; arte; psicoanálisis; imagen y contemporaneidad.

\section{Résumé}

Cet article est le résultat de la recherche: «Politiques du corps: de la psychanalyse et de l'art». La recherche donne attention aux auvres de deux artistes espagnols, Ana Casas et Mira Bernabéu, qu'au tournant du XXIe siècle, ont mis en cause le corps dans sa relation avec le lien social. La lecture de ces œuvres est soutenue par la théorie psychanalytique chez Sigmund Freud et Jacques Lacan, à travers une esthétique négative, que s'attire sur les étranges dans les images. Cette rencontre entre l'art et la psychanalyse, produit une analyse des procédures sur le corps à l'époque contemporaine, où les æuvres sont présentées, en soulignant ses singularités et similitudes thématiques. Ces connaissances sont approximées par ses politiques du corps, dans une perspective critique aux idéaux dominants de la beauté, de la jeunesse, de la santé parfaite et de la complétude. Il a été possible d'analyser la rencontre avec l'autre, avec la culture, avec les images. On a aussi aperçu comme la matérialité du corps permet de construire des idéaux naturels, au même temps qu'elle aide le sujet faire face à l'incomplétude inhérente à l'être humaine. L'article est présenté dans la structure suivante: «Psychanalyse et art: le corps politique», lequel introduit l'article et la rencontre conceptuelle; «Travail et corps» qui présente les sous-éléments suivants: «Mira» et "Casas», lequel montre les œuvres en question; «Le familier et l'étrange», dont les sous-éléments sont: "Déshabiller le corps" et "Démembrer le corps", lesquels contournent l'articulation conceptuelle entre les cuvres et les concepts psychanalytiques. E finalement, en guise de conclusion, on présente: «L'idéal du corps» dans lequel on vise à articuler les idéaux du corps à l'époque contemporaine, avec des perspectives critiques introduites par les oeuvres et par la psychanalyse.

Mots-clés: corps; art; psychanalyse; image et contemporanéité.

\section{Psicanálise e Arte: Políticas do Corpo}

O presente texto é fruto do projeto de pesquisa: "Políticas do corpo: psicanálise e arte", que propõe um diálogo entre a psicanálise, pautada na perspectiva de Sigmund Freud e Jacques Lacan, e a arte contemporânea a partir da análise de obras de arte contemporânea expostas nas principais instituições de artes de Florianópolis, na virada do milênio, que trataram da temática do corpo. Neste artigo, analisamos as obras de dois artistas: Mira Bernabéu e Ana Casas Broda, que foram expostas no ano de 2001, provenientes da seleção do acervo de fotografias espanholas da Comunidad de Madrid, intitulado "Hácia una colécion", que incluiu as obras de 30 artistas contemporâneos do país. Nosso intuito é analisar as obras pela perspectiva da psicanálise em articulação com a reflexão sobre o corpo na contemporaneidade. 
Busca-se sustentar uma perspectiva de análise psicanalítica sobre as obras, convidando o leitor a acompanhar a trajetória dessa leitura e interpretação. Partimos do significante: corpo na contemporaneidade, que conduziu nossos olhares e escolhas. Destacamos as obras que mais nos interrogaram, que dialogavam entre si e com a teoria psicanalítica. Lançamo-nos, a partir do desejo de colocar em análise essa temática, advertidos da cisão sustentada pela teoria psicanalítica, entre saber e verdade. Premissa que implica, assim, nos limites de nossa compreensão. Apresentadas as imagens, buscamos destacar suas singularidades e semelhanças temáticas. Elas, bem como a teoria psicanalítica, levaram-nos às políticas do corpo e à crítica que desdobram ante aos ideais dominantes de beleza, juventude, saúde perfeita e completude do corpo. Em outra via, psicanálise e arte sustentam o encontro com: o semelhante, o social, a cultura, as imagens e fantasias e a materialidade do corpo, como elementos indispensáveis na construção de ideais singulares e de estratégias para lidar com a incompletude inerente ao humano.

\section{Psicanálise e Arte: Políticas do Corpo}

Cabe destacar que a psicanálise é um campo híbrido por excelência, constituído a partir de um profícuo diálogo entre a ciência, a cultura e a história. A arte contemporânea, por sua vez, leva a fundo a ampliação do campo, sustentando o valor da arte enquanto ato e discurso crítico do seu tempo. Ambos são campos extremamente politizados e impuros, e possibilitam a criação de novas formas, pela desconstrução de formas cristalizadas, (trans)formam saberes e singularidades, sublinham o valor do ficcional e do desejo. A psicanálise, ao se debruçar sobre a estética, busca, para além do encontro com o belo, o lugar da inquietante estranheza, lugar que suscita a angústia, “. . . onde o que vemos aponta para além do princípio de prazer; é o lugar onde ver é perder, e onde o objeto da perda sem recurso, nos olha" (Didi-Huberman, 2010, p. 227) e nos interroga.

Deter-se ao corpo, a partir da perspectiva desses saberes, faz resistência aos ideais de nossa época, que procuram determinar o lugar do corpo como se pudesse constituir-se à revelia da singularidade que o habita. Atualmente, os discursos organicistas pré-definem sua ação; por outro lado, os discursos pluralistas, atrelados aos interesses de mercado, incentivamno a uma fluidez ininterrupta, em que tudo é possível. Conforme o sociólogo Bauman (2001), a velocidade do movimento, a liberdade sem precedentes, funciona como principal ferramenta de dominação, gerando uma impotência sem precedentes. Se, por um lado, há uma desconstrução que liberta; por outro, vemos uma desconstrução que aliena.

Preocupa o fato de que adoecer ou morrer, na contemporaneidade, pode ser lido meramente como uma resposta a uma disfunção neuroquímica, genética ou fisiológica. Nessa perspectiva política, vemos que a subjetividade está fora. O sujeito não é mais responsável por sua vida. O corpo, vinculado apenas ao seu substrato biológico, torna-se palco das manipulações humanas que buscam desvendar uma verdade que serviria para todos os sujeitos, tal qual uma essência do ser. A psicanálise, em seu posicionamento ético e em sua perspectiva crítica, “. . . restaura a ideia de que o homem é livre por sua fala e de que seu destino não se restringe a seu ser biológico” (Roudinesco, 2000, p. 9).

Se na perspectiva da psicanálise é possível falar em alguma verdade humana, é da verdade inconsciente que se trata, uma verdade mítica (Lacan, 1954/2008). É desde o inconsciente que o sujeito fala, desde a singularidade que está organizado, que pode enunciar. Não falamos de uma subjetividade fechada e rígida, mas de algo que se constrói constantemente a partir da relação com os outros, endereçada a uma rede de interlocuções. O corpo é parte intrínseca desse sujeito, não é uma propriedade subjetiva. Transformá-lo não é sem consequências. Ao mesmo tempo, não se trata de desmascarar a verdade inconsciente. Não temos como traduzi-la, ela é uma força constante que pulsa em nós.

$\mathrm{O}$ ato analítico e criativo, ao se debruçar sobre a temática do corpo, tende a revelar sua singularidade, suas marcas, detalhes e seus restos. A arte dá a ver a importância da forma e, ao mesmo tempo, nos apresenta a capacidade de abertura que pode ter um corpo. Sendo assim, o ato criativo é um ato utópico, que busca fazer um contraponto às formas instituídas, resgatando a inconsistência das imagens, a multiplicidade que nelas habitam e que estão anestesiadas pelo senso comum, pela força dos hábitos.

$\mathrm{O}$ ato analítico também é um ato utópico, pois busca possibilitar a constituição de um corpo através do resgate do seu desejo, da sua história, de um novo lugar de enunciação, indo no contrafluxo de uma práxis que se vale do poder para adestrar o outro. A psicanálise, ao colocar em análise o lugar de enunciação dos sujeitos e das produções humanas, necessariamente coloca em análise o inconsciente, o contexto, a história, a precariedade e os ideais da cultura em que o sujeito/obra se insere e incide. "A função do ato analítico é de abrir espaço para o detalhe que introduza o tempo da dúvida e o espaço da interrogação" (Sousa, 2002, p.7).

Enfatizar a singularidade do corpo, através do campo da psicanálise e da arte contemporânea pode contribuir para questionar a lógica da homogeneização das diferenças, tão presente na atualidade, bem como para restituir o valor da enunciação, das trocas e da experiência. As obras de arte se constituíram, com Freud e Lacan, como indutoras de conceitos formais imprescindíveis e constitutivos da psicanálise. Nosso esforço é o de abrir leituras para além de um formalismo tautológico da imagem, de uma hermenêutica que decifre signos universais, ou de mera ilustração de conceitos psicanalíticos. 
Direcionamos nosso debate em uma perspectiva crítica, que se debruça sobre os processos de criação implicados em um contexto histórico e político, que se inscreve a partir das obras em um diálogo com a psicanálise.

Como teoria do inconsciente, a psicanálise coloca-se enquanto saber incompleto e não tem o objetivo de compreender (Lacan, 1961/1992), mas de abrir a fenda da dúvida, analisar em profundidade as diversas faces de uma mesma questão, sabendo que não se pode dar conta da totalidade, pois sempre ficarão restos que seguirão convocando a serem analisados. Dessa forma, parte-se da premissa do inconsciente e da inviabilidade de separação completa entre observador e observado, conduzindo o pesquisador a trabalhar com: a associação livre, a atenção flutuante, a transferência, a contingência e com a concepção de a posteriori. Assim, permitimo-nos, inicialmente, uma atenção flutuante ao material coletado, destacando pontos significantes por sublinharem e possibilitarem abertura ao tema de pesquisa. A seleção se dá pelo estranhamento inicial, ou pelo que se produz ante o olhar mais insistente às obras (Didi-Huberman, 2010).

\section{Obra e Corpo}

O movimento de análise dos arquivos, que antecede a esse processo de reflexão e escrita, merece ser destacado, pois revela o movimento temporal, próprio à epistemologia psicanalítica, que busca, nessa sobredeterminação de fatores passados e futuros antecipados, refletir sobre o presente e reconfigurar esses tempos. Nesse sentido, o ato de abertura de arquivos, através de um olhar anacrônico, atualiza a obra, instaurando um a posteriori que possibilita elaborações, interlocuções, atualizações de um passado, que dizem do presente e indicam ideais.

O teórico da arte Georges Didi-Huberman (2015) auxilia nossa análise metodológica sustentando que o anacronismo é um risco dialético na leitura das obras de arte. Esse perigoso artifício é como um desvio forçado, torção da obra, que tem seu valor na abertura da história a novos objetos e modelos de temporalidade. O que se busca nesse movimento de abertura dos arquivos não é, então, uma síntese que esterilize novos sentidos. Pelo contrário, a síntese, nesse método, é algo incompleto, frágil, sempre em estado de suspensão. Falamos, assim, de uma "síntese-abertura", que é própria do ato analítico.

Detemos o olhar sobre 30 fotografias que fazem parte do acervo da comunidad de Madrid de arte contemporânea, e representam, no âmbito político, um panorama das principais obras/artistas da região na época. Algumas nos capturam, por interrogarem o ideal dominante de corpo na contemporaneidade e colocarem em questão o tema da identificação com o outro. Nos anos 90, virada do milênio, os ideais do hyper corpo lançaram-se como utopias projetistas de um futuro próximo. Nosso contexto passa a ser bombardeado por imagens ideais de um suposto corpo-máquina, que buscam, acima de tudo, a saúde perfeita, a juventude, a liberdade e a produção. Esses artistas, na contracorrente, revelam a sutileza dos detalhes, a incompletude do corpo, o sofrimento, o ficcional, a relação com o outro e o peso da história sobre o corpo. Das 30 fotografias, que compõem o catálogo "Hácia una Coleción", destacamos, no presente artigo, duas obras: "Díptico fotográfico"(Imagem 1), 1996, de Mira Bernabéu e "Autorretrato con mi abuela"(Imagem 2), 1992, de Ana Casas Broda. Escolhemos essas obras por abordarem a temática do corpo de forma impactante, dando a ver o familiar, a nudez e a agressividade que marcam o corpo.

A obra de arte pode trazer à tona um símbolo do vazio, a expressão de algo não dizível do corpo, aberto a inúmeras significações. As obras destacadas neste artigo apresentam corpos estranhos, que mesclam traços familiares, mas, em um mesmo gesto, inquietantes. Essas obras afastam-se de uma perspectiva do corpo belo, a ser mostrado e admirado, retratando corpos comuns, que se constituem pelas marcas do tempo, pelos traços familiares. São imagens que mantêm em aberto o fascínio e horror do encontro com os não sentidos do corpo e sua iminente finitude. É a partir do encontro com esse estranho que podemos fazer furo na repetição, desfazer a forma, tornando-se impossível sustentar uma unidade que não há.

\section{Mira}

Ora, o objeto, o sujeito e o ato de ver jamais se detém no que é visível (...). O ato de ver não é o ato de uma máquina de perceber o real enquanto composto de evidências tautológicas. Dar a ver é sempre inquietar o ver, em seu ato, em seu sujeito. Ver é sempre uma operação de sujeito, portanto uma operação fendida, inquieta, agitada, aberta. (Didi-Huberman, 2010, p. 76)

Em diálogo com a produção textual do teórico Georges Didi-Huberman (2010), que também se subsidia na teoria psicanalítica para analisar as obras de arte, poderíamos afirmar que as obras escolhidas nos interrogam, inquietam nosso olhar. Elas não nos apresentam uma imagem completa a ser contemplada serenamente, e sim uma hiância de sentidos, permitindo que se desdobre o ver em um olhar que interpela o observador.

As obras podem ser pensadas como metáfora de um corpo: entre sua capacidade de fazer volume e sua capacidade de se oferecer ao vazio, de se abrir; com suas entradas e saídas, relacionadas ao outro, revelando sua forma e, paradoxalmente, 
escondendo seu suposto conteúdo pleno. Obra/corpo em seu perpétuo movimento de produção de sentidos, no contrafluxo de uma suposta estabilidade da forma. Toda obra é corpo que se cria e que produz novos sentidos por sua existência.

A obra do artista espanhol Mira Bernabéu (Imagem 1) analisa as relações entre o sujeito e a sociedade, apresentandonos um díptico, uma imagem que se compõe em duas partes. O conjunto de imagens produzidas pelo fotógrafo espanhol apresenta corpos estranhos, que mesclam traços familiares, mas, em um mesmo gesto, inquietantes. Essa obra afasta-se de uma perspectiva do corpo belo a ser mostrado e admirado, retratando corpos comuns, que se constituem pelas marcas do tempo, pelos traços familiares, em imagens que mantém em aberto o fascínio e horror do encontro com os não sentidos do corpo e sua iminente finitude.

Mira Bernabéu, artista, "galerista" e acadêmico espanhol, analisa que não define a autoria da imagem fotográfica em função do ato mecânico de apertar um botão, ou mesmo do desenho de luz de uma cena. Refere que isto ele deixa às pessoas mais "competentes"; sendo o que lhe interessa de fato a construção da imagem, o conceito dela. Cabe destacar que Mira compõe esse díptico com membros da sua família, em um teatro que lhe pertence.

Sua obra apresenta uma organização familiar, aparentemente dentro da normalidade da cultura ocidental, seja pelos membros do grupo que envolvem pessoas de várias idades, seja pelas vestimentas que usam. Por outra via, parece interrogar essa organização, dando vazão a segunda imagem que compõe a obra (Imagem 1.2), que passa a colocar em questão a aparente familiaridade da primeira (Imagem 1.1). Em um a posteriori, chama atenção inclusive a formalidade das vestimentas, que parecem trazer um retrato tradicional, em uma festa de família. Entretanto, um tanto descontextualizadas do tempo em que se produz a obra. Elas dizem da tradição e nos convidam a refletir sobre seus efeitos na constituição da subjetividade e da coletividade.

A diferença substancial entre os dois quadros da imagem, em um primeiro olhar, é aquilo que envolve o corpo. Permanece a luz, o palco, as pessoas, mas a disposição dos corpos em cena não é exatamente a mesma. A diferença marcante entre as imagens está no véu que cobre o corpo. De um lado, temos "véus" familiares, roupas tradicionais e cotidianas na cultura ocidental, que nos remetem a um típico retrato de família. Do lado, no segundo quadro, o primeiro olhar é de estranhamento. Há uma subtração na imagem que nos interroga. Os "véus" que recobrem os corpos remetem ao íntimo, que não costuma ser exposto, nesta configuração coletiva em especial. A organização dessa cena faz alusão ao exótico, a um descompasso entre esse coletivo tradicional e a "nudez" com que se apresentam. Haveria, nesse sentido, um a mais a ser visto naquilo que nos parece familiar.

O olhar mais detido na segunda imagem revela a presença do sangue, que se impregna nas roupas íntimas, mas também cobre partes de alguns dos corpos que compõem a imagem. A segunda imagem coloca-nos ante a falta de sentido, causandonos um estranhamento. $\mathrm{O}$ olhar percorre as duas imagens, que ganham sentido ao serem lidas como conjunto, no qual um elemento, a posteriori, reinterpreta o primeiro. A segunda imagem é da ordem do choque, e nos leva a reler a primeira, a partir de uma montagem dialetizada que cria uma nova imagem ao conjunto. Ingressamos em um movimento de análise das duas imagens, buscando sentidos que apaziguem nosso olhar, mas o "estranho" que se abre não possibilita sínteses.

Uma análise da obra que nos levasse a uma apreensão totalizante dos sentidos a partir de uma fusão dos quadros nos pareceria contraditória a qualquer movimento crítico e seria impossibilitada pela própria ética psicanalítica que sustenta essa reflexão. A inelutável incompletude dos sujeitos implica em um confronto com a cisão, com aquilo que é da ordem do furo e da divisão, nas palavras de Lacan: "o sujeito tem sempre uma relação antecipada com sua própria realização, que o lança de volta ao plano de uma profunda insuficiência e revela nele uma rachadura, um dilaceramento original" (Lacan, 1954/2008, p.41)1. Nesse sentido, a experiência humana é sempre não toda, parcial, e as tentativas de compreensão totalizante excluem a posição do sujeito.

Parece-nos pouco profícuo cindir a imagem em dois, pensá-la de forma analiticamente separada. É justamente a dialética entre as imagens que se coloca como um movimento crítico pertinente. A relação entre os dois quadros possibilita a criação de um encadeamento que reinterpretaria as imagens, configurando o díptico como uma montagem temporal sobredeterminada. Indica, dessa forma, a crucial articulação entre a imagem, sua temporalidade, discursividade e, sobretudo, a perda de sentidos que se inscreve nesse jogo.

Os conceitos criados por Barthes em "A câmara clara" (1984) nos ajudam a pensar o díptico em uma interlocução com a psicanálise. Há, segundo o autor, diferentes tipos de afeto em uma experiência estética fotográfica. O studium seria um afeto médio, uma relação mediada pelos valores morais e culturais:

Reconhecer o studium é fatalmente encontrar as intenções do fotógrafo, entrar em harmonia com elas, aprová-las, desaproválas, mas sempre compreendê-las, discuti-las em mim mesmo, pois a cultura -com que tem a ver o studium - é um contrato feito entre os criadores e os consumidores ... é uma espécie de educação (saber e polidez) (Barthes, 1984, p. 48).

O studium é, portanto, um olhar sempre mediado pelo saber consciente, pela entrada na cultura e por suas leis

$1 \quad$ Nesse trecho, Lacan refere-se justamente à antecipação da imagem na experiência primordial frente ao espelho, em que a completude refletida entra em embate com as perturbações motoras e afetivas que o pequeno humano dispõe. Nesse tempo, sustenta-se a formação do sujeito, nessa disparidade entre imagem e experiência. 


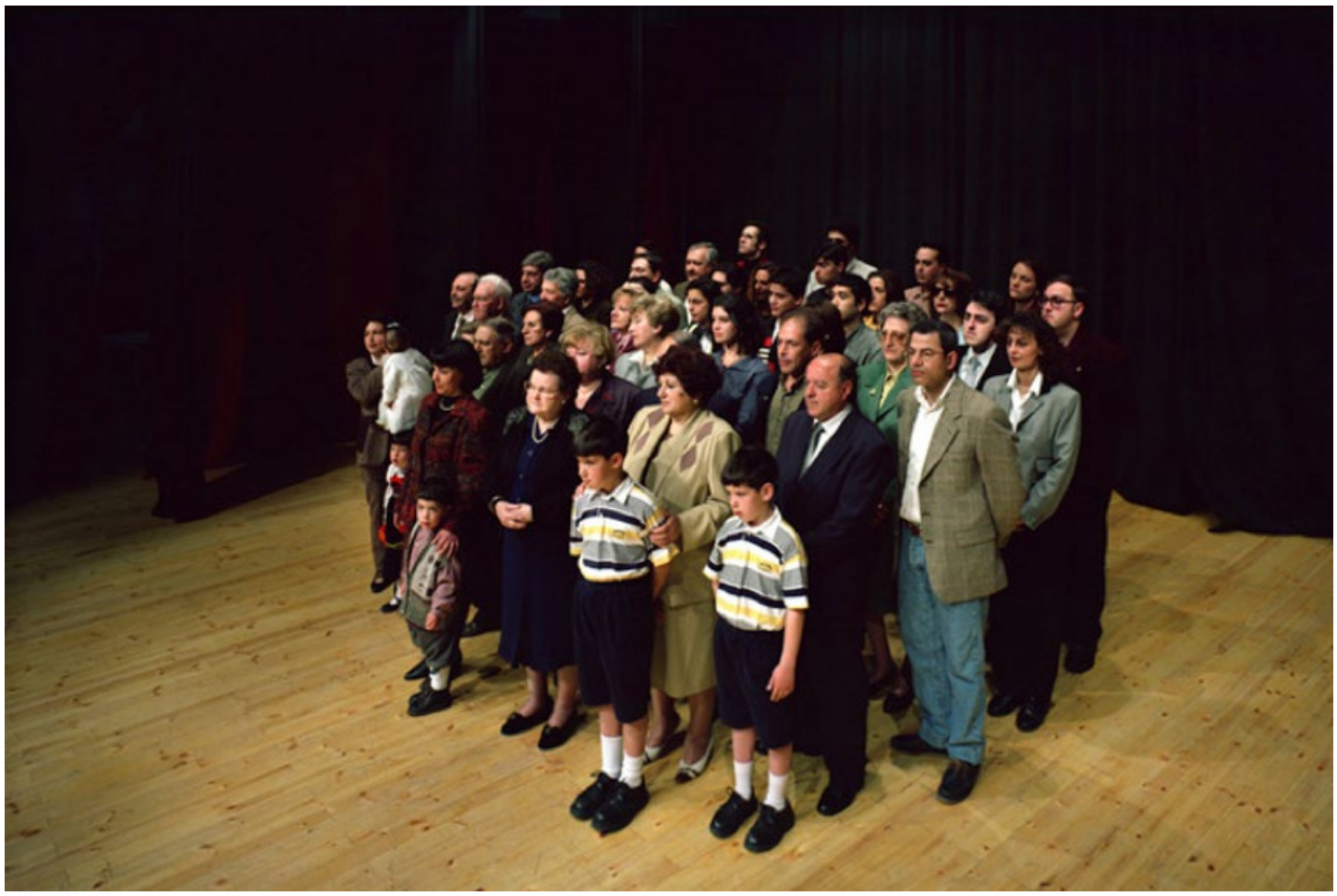

Imagem 1.1.

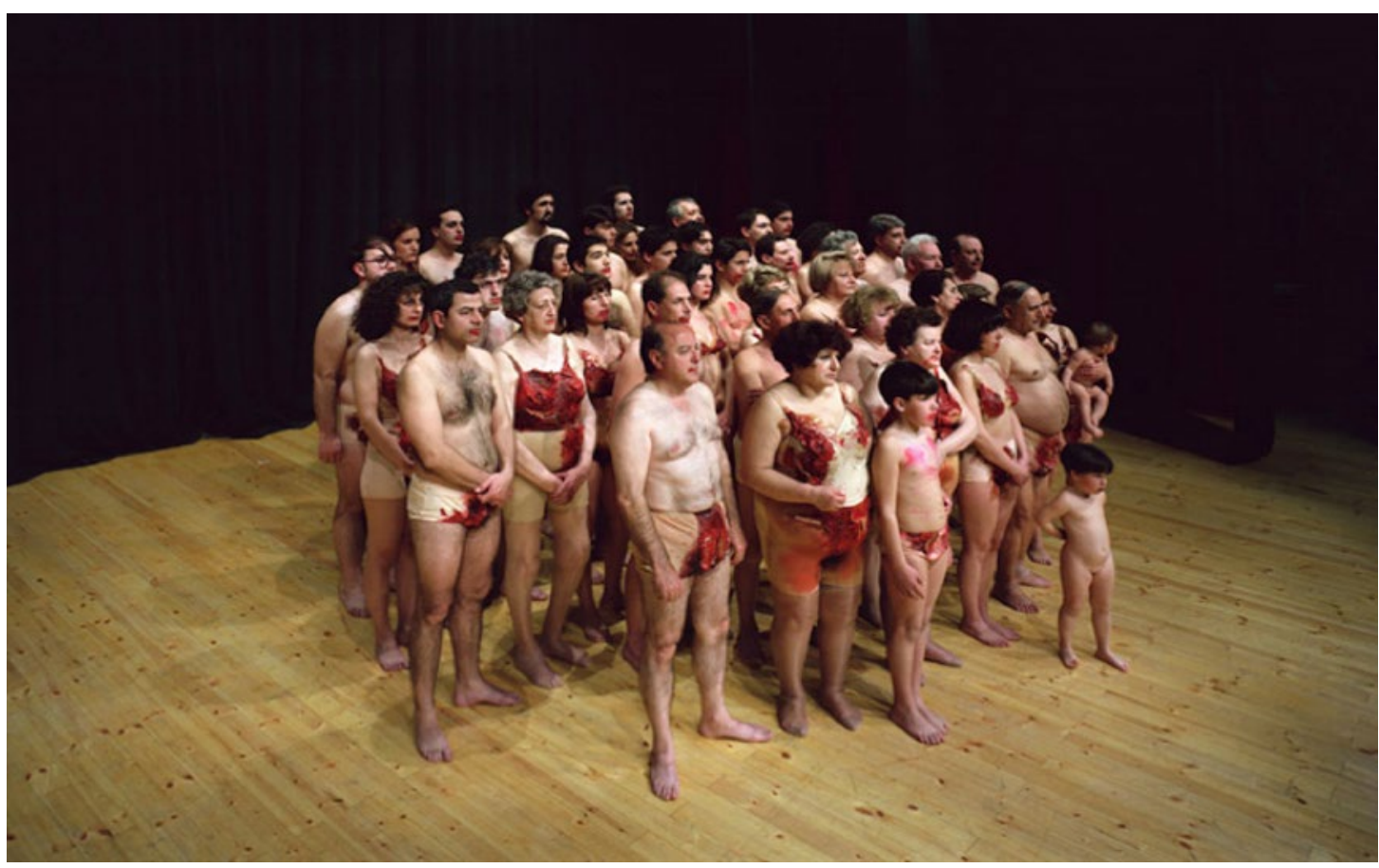

Imagem 1.2.

Imagem 1 (1.1 e 1.2). "Díptico fotográfico", 1996 , Mira Bernabéu 


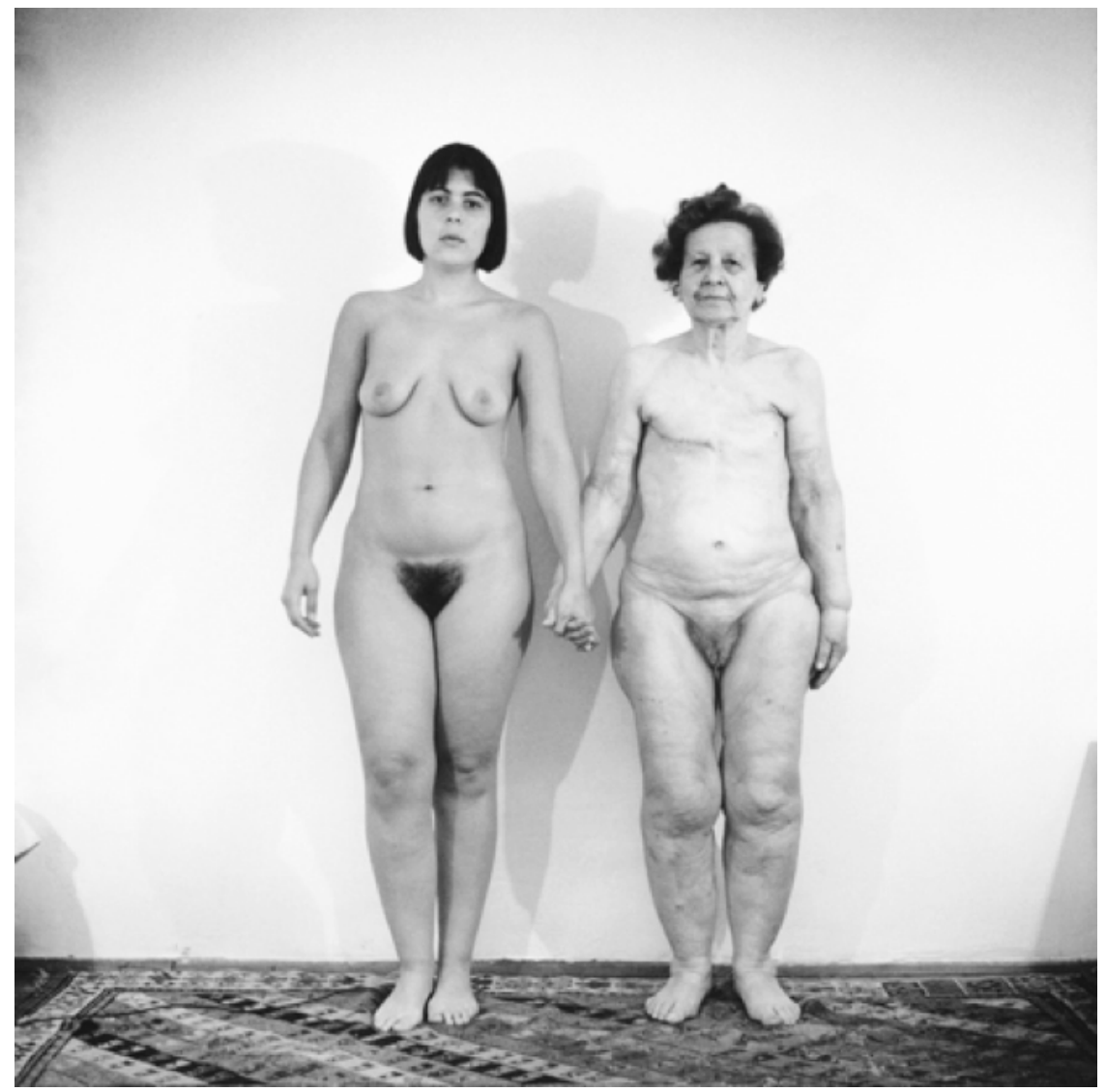

Imagem 2. Ana Casas, "Autorretrato con mi abuela”, 1992, Viena, Austria.

simbólicas. Este conceito nos remete, então, à primeira fotografia, porque a relação se estabelece não a partir do estranhamento, mas do reconhecimento do que está colocado em cena. As vestimentas, por exemplo, são traços de uma cultura que nos remetem a significados que precedem o sujeito (pré-fabricados). A disposição no palco e a representação dos papéis são alguns elementos manifestos que nos colocam como investigadores de um sentido que pode nos convocar a uma hermenêutica de conteúdos latentes.

A segunda fotografia, por outro lado, nos olha de outra perspectiva; como coloca Barthes:

O segundo elemento vem quebrar (ou escandir) o studium. Dessa vez, não sou eu que vou buscá-lo (como invisto com minha consciência soberana o campo do studium), é ele que parte da cena, como uma flecha, e vem me transpassar ... esse segundo elemento que vem contrariar o studium chamarei então punctum; pois punctum é também picada, pequeno buraco, pequena mancha, pequeno corte . . . O punctum de uma foto é esse acaso que, nela, me punge, me fere. (Barthes, 1984, p. 46)

Dessa forma, a primeira imagem de Mira Bernabéu remete ao familiar, e nos leva mais facilmente a pensar, a partir da ideia de studium de Barthes, que diz respeito a um âmbito de valores culturais, símbolos, de um olhar mediado pelo saber e pela entrada na cultura. A segunda foto, que nos olha e nos punge, é da ordem do choque, ou como coloca Barthes, do Real lacaniano "o que posso nomear não pode, na realidade, me ferir" (Barthes, 1984, p.80). Aquilo que punge não é o que podemos representar da imagem, mas o que escapa da possibilidade de um olhar atribuir um significado certeiro.

\section{Casas}

Ana Casas é uma artista espanhola, que, desde seus nove anos, vive no México. Estudou fotografia, pintura e história, dedicando-se a fotografia desde 1983. As fotografias tiradas com sua avó fizeram parte, primeiramente, de uma série de imagens do projeto "Álbum", no qual a artista trabalhou por quatorze anos. Posteriormente, a obra tornou-se parte do livro 
com o mesmo nome. Com a publicação do livro, em 2000, foi realizada uma exposição baseada na obra que incluiu outros materiais, como vídeos, áudios e diários. A memória, a relação entre presente e passado, imagens do corpo e relações familiares são temas centrais das obras da artista.

A obra de Ana Casas Broda (Imagem 2), como o próprio nome indica, é um autorretrato da artista com sua avó, na qual ela joga com sua imagem e a da avó, interrogando histórias, relações entre a casa, o corpo, as memórias e heranças. Sua avó já mantinha o hábito de fotografar, e a artista, em muitos de seus trabalhos, vale-se dessas memórias visuais para refletir sobre a questão da identidade.

A imagem em questão aborda as marcas do tempo, a dimensão do familiar e do estranho que se apresenta no corpo. A lógica do duplo se faz presente, tornando inevitável realizarmos certo espelhamento entre os corpos, aproximando suas semelhanças e diferenças. As mãos dadas parecem indicar uma dimensão de cumplicidade entre elas, o que suaviza a imagem em um primeiro olhar. Porém, pelo espelhamento dos corpos e pela percepção das marcas do tempo sobre eles, revela-se que a cumplicidade ali presente poderia ser de uma condição de precariedade que é compartilhada. Essa condição coloca o corpo jovem da fotógrafa não como um sujeito que se compadece pela situação da avó, em um local de privilégio, quanto aos efeitos da temporalidade no corpo, mas como o de um outro que compartilha o limite e a fugacidade do corpóreo que está para todos.

O estranho está presente, seja pela nudez, dissimetria entre os tempos, ou pela marca da falta, que constitue a imagem. A nudez da avó estampa o vazio que a mastectomia escancara. Se a precariedade nos constitui, a amputação do corpo, sofrida pela avó, reafirma o despedaçamento constituinte do corpo. Mas poderíamos afirmar que não é apenas dessa perda que se trata, pois a diferença temporal apresentada confronta-nos com a inevitável transformação.

Nesse sentido, a obra possui um anacronismo entre diferentes tempos do corpo presentes na mesma imagem. Ao colocar em evidência essa dimensão anacrônica, sublinha a posição dos sujeitos na condição de cúmplices do destino corporal, em suas faltas, falhas e transitoriedade. As marcas da temporalidade em um contrastam imageticamente com o outro. Porém, os corpos não se mostram em oposição, mas em uma relação dialética, na qual as marcas do tempo expõem, de forma fantasmática, a condição da falta.

Outra dimensão desse anacronismo acontece na própria fotografia como registro de memória. A arte de Ana Casas aborda a temática da constituição de uma história, não em sua linearidade, mas justamente na perspectiva da sobreposição dos tempos:

Uniendo su propio trabajo fotográfico con el de su abuela, Ana Casas ha compuesto una historia familiar que es un testimonio muy audaz de la forma en que el sucederse de las generaciones no es una línea vacía y recta, sino el recorrido ondulado por la resonancia entre los cuerpos, la comunidad de las imágenes y la repetición de la dicha y el infortunio eróticos (Medina, 2016, para. 2).

\section{O Familiar e o Estranho}

"O inquietante" Freud (2010a) - o estranho, na tradução mais difundida- é um dos raros textos em que Freud se sente instigado a desenvolver o que ele chama de "investigações estéticas". Reflete para além de uma teoria do belo, pois se ocupa, no campo da estética, sobre o que nos é inquietante, estranho. Sua epistemologia o conduz a um recorte sobre o problema da estética a partir do conceito cunhado pela psicanálise de inconsciente. Nesse sentido, interroga-se sobre as qualidades do sentir.

No texto "Dasunheimlich", Freud se propõe a identificar o que seria esse elemento de inquietante estranheza que identificamos, a partir da experiência estética, no núcleo de uma impressão que desperta "angústia e horror". Sua investigação toma dois caminhos;, antecipa, no entanto, que os dois levam ao mesmo lugar.

O inquietante (unheimilich) é aquela espécie de coisa assustadora que remonta ao que é há muito tempo conhecido, ao bastante familiar. Como isto é possível, sob que condições o familiar pode tornar-se inquietante, assustador, deverá ser mostrado (Freud, 2010a, p. 331).

O primeiro caminho o leva a uma busca em dicionários por uma via de análise semântica e comparativa da palavra unheimilich. Há no significante (na língua alemã) uma oposição de sentidos, fundamental no interior do pensamento psicanalítico, que é a existência estruturante da divisão e do contraditório. Assim, o significante é cindido: o un, apresenta-se enquanto negação (recalque), e heimlich, enquanto sentido contrário ao significado que a palavra evoca. Heimlich derivaria de um sentido familiar, "doméstico", adjetivo do substantivo heim que, em alemão, tem significado aproximado de "lar", equivalente ao inglês home. $\mathrm{O}$ achado de Freud nos dicionários é que a própria palavra heimlich carrega sentidos para além do "doméstico", podendo ser entendido também como "escondido, mantido oculto". E, para além de um significado apenas 
alheio, heimlich "desenvolve seu significado na direção da ambiguidade, até afinal coincidir com seu oposto. "Unheimilich é, de algum modo, uma espécie de heimlich.” (Freud, 2010a, p.340).

A experiência do estranhamento, portanto, se inicia - mas não se esgota - quando o olhar da dedução de sentidos não dá conta de compreender uma imagem, quando a imagem nos aponta para uma falta a ser constitutiva do sujeito que olha $\mathrm{e}$ que passa, então, a ser olhado.

Associando a temática do estranho à metapsicologia freudiana das pulsões (2010b), somos levados a pensar sobre a produção de sentidos diante de uma obra, a partir do olhar enquanto inserido no campo das pulsões, ou seja, no que envolve a relação entre o corpo e o outro. O olhar em psicanálise, tomado na perspectiva da pulsão escópica, tem, como um de seus destinos, a reversão ao seu oposto. Nesse sentido, somos interrogados por aquilo que olhamos. Deparar-se com a inquietante estranheza da obra assinala o lugar que suscita a angústia, que nos interroga.

A experiência do olhar na obra de Mira e na obra de Casas nos remete, assim, a dois conceitos freudianos importantes: $a$ posteriori e estranho. Na obra de Casas, atravessam a relação entre os dois corpos que compõem a imagem, e no díptico de Mira, a relação entre as duas imagens. O retorno, a posteriori, remete não só à estrutura temporal presente na teoria freudiana do trauma, na qual uma segunda imagem/experiência dá sentido a um registro de memória, mas também ao movimento dialético de uma montagem entre dois registros, que não cessam de construir novas imagens, estranhas e ambíguas. $\mathrm{O}$ unheimlich, analisado por Freud (2010a, p.331), nos "remonta ao que é há muito tempo conhecido, ao bastante familiar", mas também desloca uma posição subjetiva, na qual o que antes era familiar parece também estranho. Mira e Casas colocam em ato performances do estranho e do tempo que constituem o corpo.

\section{Despir a Imagem}

Nas duas obras escolhidas para análise encontram-se presentes a questão do corpo, especificamente do corpo despido. No caso da obra de Ana Casas (Imagem 2), a nudez encontra-se diretamente expressa pela imagem dos dois corpos nus. Já na obra de Mira Bernabéu (Imagem 1), a nudez está presente no contraste entre as duas imagens que compõem a obra. A primeira imagem mostra um grupo de pessoas com vestimentas cotidianas. Na segunda imagem, o mesmo grupo de pessoas encontra-se despido de suas roupas, sendo que a maioria delas está somente vestida nas partes íntimas. Os corpos encontram-se quase totalmente expostos na segunda imagem. É o jogo de presença/ausência das vestimentas na obra, porém, que expressa a temática da nudez.

Cabe refletir que nudez é essa que está presente nas obras, já que não se trata do nu das esculturas da Grécia antiga, tampouco do nu encontrado nas revistas atuais. $\mathrm{O}$ nu que encontramos nessas obras não exaltam nem erotizam o corpo. $\mathrm{O}$ arranjo estético da obra "Autorretrato con mi abuela" (Imagem 2) não procura esconder a organicidade dos corpos femininos. Eles estão apresentados de frente para o espectador, eretos e inertes. Não há artifícios para acentuar simetria, tônus ou harmonia estética desses corpos. Trata-se da nudez que socialmente procura-se esconder: nua de roupas e de idealizações, aquela que vestimos para tapar. Vestimos, pois, em certa medida, incomoda essa nudez. Sendo assim, as roupas fazem a função do véu (Quinet, 2002), pois, enquanto expressam algo na superfície, velam o corpo, a falta. São nessas duas funções da vestimenta que encontraremos o que angustia na nudez presente nas duas obras. Como bem analisa o psicanalista Antônio Quinet (2002): "O vestido tem a mesma função do véu. Lá onde o véu esconde a falta, o vestido esconde a nudez e o vazio recebe a marca do sexual que conota a vacuidade do ser" (p. 135).

As imagens corporais podem facilmente inquietar algo no sujeito que olha, pois essas remetem diretamente a outro ser em sua relação de diferença e semelhança. Diferente, pois é outro, mas semelhante, pois é um inteiro e faltoso como eu. Essa inquietação revela a função constitutiva da imagem do corpo, que se inicia na fase denominada por Lacan como estádio do espelho. Lacan (1966/1998) refere-se a esse momento específico da vida do bebê, quando começa a reconhecer-se no seu reflexo na presença de outro, que o acompanha. Em outras palavras, identifica-se com a imagem do espelho. Um reconhecimento que ocorre enquanto a motricidade ainda oferece uma experiência fragmentada e frágil do controle dessa corporeidade.

Em contraposição a essa vivência descoordenada do corpo, o espelho oferece a imagem de um todo; de um corpo que tem suas bordas definidas e forma uma unidade em si. “. . . Simboliza-se oniricamente por um campo fortificado, ou mesmo um estádio, que distribui da arena interna, até suas muralhas ..." Lacan (1966/1998, p.100). Essa imagem possui um caráter alienante, na medida em que oferece a um sujeito faltoso uma suposta completude. Produz uma forma primordial, que se constitui como matriz e origem das demais identificações. Sendo assim, a imagem completa de um corpo aliena o sujeito em uma linha ficcional, miragem de um eu ortopédico, que se antecipa às determinações sociais e agressivas da relação com o outro.

A partir desse primeiro tempo de constituição subjetiva, é necessário considerarmos a diferença entre o esquema corporal, que é a materialidade do corpo, e a imagem inconsciente do corpo, que indica a perspectiva inconsciente da corporalidade para o sujeito. $\mathrm{O}$ esquema corporal pode não mostrar diferenças tão expressivas para sujeitos de idades semelhantes, porém as imagens inconscientes sobre esses corpos se mostrarão peculiares, pois estão vinculadas ao sujeito e à sua história (Dolto, 2012). 
A dimensão imaginária do corpo constitui-se pela imagem propriamente dita e pelas fantasias. Esse movimento é constante, desdobrando-se no entrelaçamento entre o que é falado sobre o corpo, sua inserção na cultura, a experiência pulsional e a percepção do corpo como unidade. A demanda do outro sobre o corpo do sujeito marca a constituição do corpo, começa na busca de satisfação e desdobra-se na autoridade parental, passando para uma demanda percebida como da cultura e do coletivo, do Outro. Esse processo inclui, desde as primeiras demandas da infância, de ser um corpo que se alimenta, que possui controle do esfíncter, que oraliza, que marcha; até as demandas de um corpo produtivo, saudável e belo. Os significados míticos criados para esse corpo, a partir dessas experiências, irão constituir a imagem inconsciente do corpo. Esta terá efeitos sobre a realidade psíquica do sujeito e interferir diretamente em seu esquema corporal.

As diferentes perspectivas culturais influenciam diretamente nas imagens inconscientes do corpo. Sendo assim, é possível analisar que a imperfeição corporal está, cada vez mais, vinculada a um sentido mortífero, pois o distanciamento da imagem ideal de corpo, na contemporaneidade, através da boa forma e da saúde perfeita, é simbolizado como equivalente a uma aproximação imediata do destino de todos corpos: a morte. Caso o corpo apresente imperfeições, assimetrias, deformidades, cabe a ele também o caráter de finitude.

É interessante observar a relação entre o "corpo sarado", termo informal para um corpo dentro dos padrões estéticos, e o significado de "sarado", curado de seus males (Ramos \& Goldenberg, 2002). Cabe considerar, que o mal-estar é inerente à existência humana, visto que somos sujeitos de linguagem, sempre incompletos. $\mathrm{O}$ corpo sarado que se busca na contemporaneidade não diz da sua falta, apresenta-se no lugar de objeto desejado. Nesse sentido, entra em embate com a condição de sujeito desejante e faltoso, uma vez que, fixado nessa imagem completa do corpo, traça uma busca incessante por completude e perfeição.

$\mathrm{Na}$ busca do corpo perfeito é possível que o sujeito, através de muito dispêndio de energia e luta contra a anatomia e o tempo, busque modificar seu esquema corporal para assemelhar-se aos dos modelos corporais divulgados e vendidos midiaticamente. Aproximando-se desse objetivo, não surpreende que o sujeito perceba que a incompletude não cessa de se apresentar. O esquema corporal já pode encontrar-se semelhante ao corpo vendido como "em forma". Porém, a imagem inconsciente permanece de um corpo incompleto, que pulsa e se transforma permanentemente. A busca pode continuar assumindo formas cada vez mais caricatas, deformando-se, nos excessos, ao acentuar hiperbolicamente as características desejadas a princípio. Esses casos mostram como o objetivo não se limita somente na apresentação de um corpo esteticamente agradável, mas em um esgotamento das expressões da castração, da incompletude, que a corporalidade escancara. A anorexia e a vigorexia são nomenclaturas de patologias que mostram justamente as diferenças entre a materialidade do corpo e a imagem inconsciente do corpo percebida pelo sujeito.

A nudez em questão nas obras não se define pela exposição corporal. Inseridas no imaginário contemporâneo, o indecente não está no corpo exposto, está principalmente no corpo "fora de forma" (Ramos \& Goldenberg, 2002). Assim, enquanto a exposição corporal tem se mostrado cada vez mais frequente, há também uma menor capacidade de suportar as imperfeições do corpo. O véu das vestimentas está, sobretudo, escondendo a incompletude humana, e não necessariamente a materialidade do corpo.

Dessa forma, junto com a ausência de roupas, não há nada que esconda a falta dos corpos presentes na obra de Ana Casas. Não há investimentos estéticos para elevar o corpo humano à suposta perfeição, não há "boa forma", nem se apresenta uma "forma boa" para velar a corporalidade. É nesse ponto em que o nu das obras inquieta. É possível olhar o corpo nu, porém, quando ele revela a imperfeição do humano, a parte da imagem que nos olha se torna inelutável, pois está sustentada por uma perda (Didi-Huberman, 2010).

A mesma nudez encontra-se na obra de Mira Bernabéu, porém, a presença comparativa das duas imagens deixa exposto o jogo do véu, entre o velado e o aparente. A harmonia do grupo, na primeira imagem, pode estar associada às vestimentas, atreladas ao cotidiano e familiar. O estranho aparece na segunda cena, em que as primeiras vestimentas estão ausentes e as novas aparentam estarem manchadas de sangue, remetendo à nudez e violência. As vestimentas da primeira imagem colocam o corpo humano elevado pela cultura, pertencente a um coletivo solene e civil. Na segunda imagem, os corpos mostram aquilo que a cultura não conseguiu elevar, algo agressivo, ferimento, desmembramento e violência.

\section{Desmembrar o Corpo}

É possível pensar que o jogo do espelhamento, presente nas duas obras, traga consigo aquilo que há de agressividade velada na própria inserção à cultura. Analisaremos, com elas, que a agressividade é constituinte do eu, assim como permeia o laço social.

A nudez e a precariedade do corpo, presente em ambas as obras, expostas em dissonância com os ideais de beleza de nosso tempo, foram analisadas como capazes de fazer cair a elevação cultural e revelar aquilo que é velado: a paradoxal condição do sujeito em sua falta a ser. 
A ausência do seio da avó, na obra de Ana Casas, expõe o desmembramento do corpo. As vestimentas manchadas de vermelho, presentes no díptico de Bernabéu, remetem-nos ao sangue, que provoca um sentimento de horror e perigo. Esse fluido ao marcar o corpo e as vestimentas sugere o rompimento das bordas da unidade corporal. O sangue e o desmembramento nos expõem ao Real do corpo, sua carne, seus órgãos. A integridade da forma e das bordas corporais remetem simbolicamente ao essencial da vida, enquanto a perda dessa condição remeteà precariedade e à violência física.

Considerando ainda esse jogo do díptico de Mira Bernabéu, analisa-se que a violência, aparente na segunda imagem, já se mostra presente na primeira de forma velada, como se fosse inerente à organização sociocultural que dá a ver. No grupo familiar, representado pelo coletivo da primeira imagem, estaria velada uma violência presente como característica constituinte desse grupo. Não se trata então de uma contraposição entre o grupo inserido na cultura e o grupo propenso à violência, uma vez que se revela o que há de violência e barbárie, no próprio processo de inserção cultural.

Lacan, no seu texto "A agressividade em psicanálise", escrito em 1948, analisa a intenção de agressão sobre as pessoas que nos são mais próximas e o quanto ela "corrói, mina, desagrega: ela castra; ela conduz à morte" (Lacan, 1966/1998, p. 107). O grupo familiar, nesse sentido, produz um registro de experiência, por onde a agressividade se expressa pela simples presença do outro. As obras escolhidas dão a ver as intenções agressivas que constituem o corpo na sua relação com a cultura, da qual a família é o primeiro grupo com a função de inserir os sujeitos nesses registros compartilhados. Associadas às imagens de mutilação, desmembramento, furo ou corte, dão a ver a perda que habita o corpo.

Há uma especificidade sobre as obras de Bernabéu e Casas que diz, justamente, dessa inserção inicial ao simbólico através da organização familiar. Os pais, avós, irmãos, tios, primos são os primeiros outros, que introduzem e compartilham com os sujeitos as significações ante ao mal-estar que habita a vida. Essas relações são permeadas de amor e agressividade, que comportam esse complexo processo de transmissão e identificações. Essas imagens reforçam a função desses primeiros outros privilegiados, representantes do Outro, que inserem simbolicamente o sujeito na cultura, pela via do laço familiar.

O infans é acolhido pelo grupo sem ter escolha de não o fazer, mas é também através dessa inserção que se constitui como alguém desejado e que pode tornar-se sujeito para fazer escolhas. Essa relação paradoxal é simbólica e imaginária, mas também Real, da ordem do traumático, do excesso, que se antecipa à significação precária, procedendo-o na condição de sujeito desejante. As imagens de desmembramento corporal que atormentam os homens, fantasmagóricas, expressam as fantasias agressivas que constituem o corpo a partir da sua relação de identificação imaginária com o outro, seu semelhante e com o Outro, abstração do social e das leis.

A forma completa do corpo, que se antecipa no estádio do espelho, analisado por Lacan, produz essa relação homeomórfica com o outro, constituindo um transitivismo primordial, em que o que o outro sente é sentido pelo sujeito. Poderíamos falar, assim, de uma ambivalência estrutural produzida pelo espelhamento com o semelhante, expressa na progressiva decadência e mutilação do corpo que podemos analisar na obra de Ana Casas; bem como nos corpos despidos e marcados pelo sangue da segunda imagem de Mira Bernabéu. A alienação do sujeito ante a imagem completa do corpo produz como contrapartida o conflito com esse outro que, na relação especular, supostamente poderia tornar-se um igual, duplo. Mas, sendo assim, estaria aniquilado como sujeito, que tem como condição existencial sua singularidade. A fortaleza em que o Eu se constitui é frágil e teme ser ameaçada, pois é à medida que o sujeito se identifica com o outro, que passa a se perceber como um. A rivalidade com o pai e entre os irmãos é a expressão dessa agressividade primordial e constituinte. Esses tensos encontros entre o eu e o outro se expressam nessas obras pela trama de fantasia que elas colocam em jogo.

\section{Ideal do Corpo}

As obras analisadas colocam em cena imagens que vão na contracorrente do corpo ideal que vemos na contemporaneidade. Enquanto o corpo belo e jovem exalta a completude da imagem, o corpo saudável tende a estar atrelado exclusivamente ao seu conteúdo orgânico. O corpo ideal assujeita, não direciona; lança o sujeito em uma busca mortífera.

Ao idealizar a saúde plena, a eterna juventude, ou mesmo o corpo máquina, fantasias dominantes na contemporaneidade, supõe-se o apagamento das diferenças e o preenchimento da incompletude. Em condição de igualdade, o sujeito se fragiliza, atormentado pelo duplo que anuncia sua morte e pela agressividade que recai, sobretudo, nele próprio, e não na sobredeterminação com o laço social. O sujeito contemporâneo, em busca do corpo ideal, fascinase pela imagem completa e aguça o laço com o outro na perspectiva paranóica. Afinal, haveria um Outro, constantemente apresentado pela mídia, que "consegue" ser perfeito e completo. Cabendo também ao sujeito mostrar-se completo nas redes sociais e no palco da vida.

Cabe resgatar que, se por um lado, o laço social envolve uma agressividade intrínseca, que diz do processo de singularização do sujeito; por outro, são os significantes introduzidos pelo Outro primordial, do qual os pais e a família são os principais representantes, que constituem o ideal do eu. Este é uma trama apaziguadora da agressividade, instaurando ideais 
a serem buscados pela normatividade e inserção cultural (Lacan, 1966/1998). Constitui-se, assim, a partir da articulação com o registro simbólico, instaurado pela função paterna.

A fragilidade do laço social na atualidade faz-se cada vez mais evidente. Torezan e Aguiar (2011) analisam o sujeito contemporâneo pela perspectiva da psicanálise e sustentam que frente ao Outro, supostamente não barrado, há uma falência do sujeito, na crença em que, através do discurso da ciência e do capital, obterá a anulação da falta. Ante a completude do Outro, abstração do social, que sustentaria que tudo é possível, o corpo, na contracorrente, seria a insistência material da incompletude do sujeito.

A fragilidade do laço contemporâneo revela-se, justamente, na sobreposição das relações imaginárias sobre as simbólicas e sobre a dimensão da experiência. A relação em espelho com o outro é constituinte, na medida em que ela inscreve uma marca, um traço e movimenta o sujeito para além. Entretanto, se há um excesso na perspectiva puramente imaginária, o sujeito passa a ser ameaçado pelo Outro completo que poderia lhe aniquilar.

Ao não alcançar a completude desejada, o sujeito se sente culpado e com dificuldade de remeter seu mal-estar ao laço social, o que poderia produzir deslocamentos. Mas "a culpa é sempre preferida à angústia", como bem indica Lacan, 1963/2005, p. 33). Pela culpa, o sujeito se mantém em uma posição narcísica de controle, sustentado por uma relação causal linear entre ato e consequência. A angústia, por outra via, traz a dimensão do caótico, do sem sentido e do Real. Apresentase, justamente, quando há a fantasmática da supressão da diferença, no engolfamento do eu pelo Outro. Ela indica que algo precisa se transformar para que se sustente a singularidade.

Se, na contemporaneidade, podemos analisar certa fragilização da função paterna, ela decorre da carência de ideais simbólicos compartilhados, ofuscados pelo brilho da suposta completude das imagens. O culto da normalidade (Roudinesco, 2000) e da perfeição produzem ódio à diferença e agravam o individualismo, no qual se pressupõe prescindir do laço social. O domínio da lei sucumbe ante a promessa de superação constante. Os ideais de completude atrelados ao corpo carecem de sustentação simbólica e tendem a certa homogeneização, ao apagamento das diferenças, aguçando a agressividade, que se transforma em violência ao outro, que supostamente poderia responder a esse Outro não barrado.

As imagens de Ana Casas e Mira Bernabéu inquietam esses ideais, expõem um estranho, que suscita a angústia e, com ela, uma perda. Corroboram a perspectiva psicanalítica de que nosso corpo se constitui na relação com o outro e com o Outro, sem tamponar a agressividade que está atrelada a esse processo. Ao reconhecer o valor dos traços simbólicos transmitidos pela cultura, não omitem o mal-estar que permeia a vida e que não cessa de se revelar pela incompletude do corpo. É pela perda, pela precariedade, que se possibilita a transformação do eu (Lacan, 1963/2005) e, acrescentaríamos, do corpo. Nesse sentido, possibilita-se uma torção do corpo ideal ao ideal do corpo. Com a psicanálise, podemos concluir que é no encontro entre o imaginário, o simbólico e o Real do corpo que se constroem ideais de corpos singulares e parciais, tendo como correlatos a sustentação da diferença no laço social.

\section{Referências}

Barthes, R. (1984). A câmara clara: Nota sobre a fotografia. Rio de Janeiro: Nova Fronteira.

Bauman, Z. (2001). Modernidade liquida. Rio de Janeiro: Jorge Zahar.

Didi-Huberman, G. (2010). O que vemos, o que nos olha. São Paulo: Editora 34.

Didi-Huberman, G. (2015). Diante da imagem. Belo Horizonte: Editora UFMG.

Dolto, F. (2012). A imagem inconsciente do corpo. São Paulo: Perspectiva.

Freud, S. (2010a). O inquietante. In S. Freud, Obras completas, volume 14: História de uma neurose infantil ("O homem dos lobos”), Além do princípio do prazer e outros textos: 1917-1920 (pp. 329-376). São Paulo: Companhia das Letras.

Freud, S. (2010b). Os instintos e seus destino. In S. Freud, Obras completas, volume 12: Introdução ao narcisismo, ensaios de metapsicologia e outros textos:1914-1916 (pp.14-50). São Paulo: Companhia das Letras.

Lacan, J. (1992). O seminário: Livro 8: A transferência. Rio de Janeiro: Zahar. (Originalmente publicado em 1961).

Lacan, J. (1998). Escritos. Rio de Janeiro: Zahar. (Originalmente publicado em 1966). 
Lacan, J. (2005). Nomes-do-pai. Rio de Janeiro: Zahar. (Originalmente publicado em 1963).

Lacan, J. (2008). O Mito individual do Neurótico, ou, A poesia e a verdade na neurose. Rio de Janeiro: Zahar. (Originalmente publicado em 1954).

Medina, C. (2016). Una línea ondulada. Link

Quinet, A. (2002). Um Olhar a Mais. Rio de Janeiro: Zahar.

Ramos, M., \& Goldenberg, M. (2002). A civilização das formas: o corpo como valor. In M. Goldenberg, Nu \& vestido: dez antropólogos revelam a cultura do corpo carioca (pp.79-137). Rio de Janeiro: Record.

Roudinesco, E. (2000). Por que a Psicanálise? Rio de Janeiro: Jorge Zahar.

Sousa, E. (2002). Por uma cultura da utopia. Porto Alegre: Ed. UFRGS.

Torezan, Z., \& Aguiar, F. (2011). O sujeito da psicanálise: Particularidades na contemporaneidade. Revista Mal-Estar e Subjetividade, 11(2), 525-554.

\section{Endereço para correspondência}

Ana Lúcia Mandelli de Marsillac

Email: ana.marsillac@ufsc.br

Tomás da Cunha Tancredi

Email: tomastancredi@gmail.com

João Gabriel Neves de Sousa

Email: jgneves2@hotmail.com 